\title{
Lactoferrin from Milk: Nutraceutical and Pharmacological Properties
}

\author{
Francesco Giansanti ${ }^{1,2}$ *, Gloria Panella ${ }^{1}$, Loris Leboffe ${ }^{3}$ and Giovanni Antonini ${ }^{2,3}$ \\ 1 Department of Health, Life and Environmental Sciences, University of L'Aquila, L'Aquila I-67100, Italy; \\ gloria.panella86@gmail.com \\ 2 Interuniversity Consortium on Biostructures and Biosystems INBB, Rome I-00136, Italy; \\ giovanni.antonini@uniroma3.it \\ 3 Department of Sciences, Roma Tre University, Rome I-00146, Italy; loris.leboffe@uniroma3.it \\ * Correspondence: francesco.giansanti@cc.univaq.it; Tel.: +39-0862-433245
}

Academic Editor: Dario Donno

Received: 29 July 2016; Accepted: 21 September 2016; Published: 27 September 2016

\begin{abstract}
Lactoferrin is an iron-binding protein present in large quantities in colostrum and in breast milk, in external secretions and in polymorphonuclear leukocytes. Lactoferrin's main function is non-immune protection. Among several protective activities shown by lactoferrin, those displayed by orally administered lactoferrin are: (i) antimicrobial activity, which has been presumed due to iron deprivation, but more recently attributed also to a specific interaction with the bacterial cell wall and extended to viruses and parasites; (ii) immunomodulatory activity, with a direct effect on the development of the immune system in the newborn, together with a specific antinflammatory effects; (iii) a more recently discovered anticancer activity. It is worth noting that most of the protective activities of lactoferrin have been found, sometimes to a greater extent, also in peptides derived from limited proteolysis of lactoferrin that could be generated after lactoferrin ingestion. Lactoferrin could therefore be considered an ideal nutraceutic product because of its relatively cheap production from bovine milk and of its widely recognized tolerance after ingestion, along with its well demonstrated protective activities. The most important protective activities shown by orally administered bovine lactoferrin are reviewed in this article.
\end{abstract}

Keywords: lactoferrin; transferrins; nutraceutical; iron

\section{Introducing Lactoferrin}

Lactoferrin (Lf, formerly known as lactotransferrin) is an iron-binding glycoprotein, belonging to the transferrin protein family, together with serum transferrin (sTf), ovotransferrin (Otrf), melanotransferrin and the inhibitor of carbonic anhydrase. Lf was first isolated by Sorensen and Sorensen from bovine milk in 1939 and after two decades it was determined to be the main ironbinding protein in human milk [1,2]. Lf is produced and released by mucosal epithelial cells and neutrophils in various mammalian species, including humans, bovines, cows, goats, horses, dogs and several rodents. More recently [3] González-Chávez et al. showed that Lf is also expressed in fishes.

Lf has been shown to be involved in several physiological and protective functions, including regulation of iron absorption in the bowel; antioxidant, anticancer, antinflammatory and antimicrobial activities, which are the most widely studied function to date [4-12]. Interestingly, a great number of Lf activities are present also in ovotransferrin, an avian homologue of mammalian Lf, indicating that they have been conserved during evolution $[13,14]$. Beside mammalian milk and colostrum, where Lf, present at a concentration of $7 \mathrm{~g} / \mathrm{L}$, is the second most abundant protein after caseins $[15,16]$, Lf is primarily found in mucosal secretions; in particular it is present in tears, saliva, vaginal fluids, semen [17], nasal and bronchial secretions, bile, gastrointestinal fluids, and urine [18]. It is also found 
in considerable amounts in secondary neutrophil granules ( $15 \mu \mathrm{g} / 10^{6}$ neutrophils) [19], where it plays a significant physiological role and it can also be found in bodily fluids such as blood plasma and amniotic fluid.

Lf is an $80 \mathrm{kDa}$ glycosylated protein of about 700 aminoacids (711 aa for human Lf (hLf) and 689 aa for bovine Lf (bLf)) with high homology among species. Its three dimensional structure consists of a single polypeptide chain folded into two symmetrical lobes ( $\mathrm{N}$ and $\mathrm{C}$ lobes), which are highly homologous with one another (33\%-41\% homology) (Figure 1) [10,20-23].

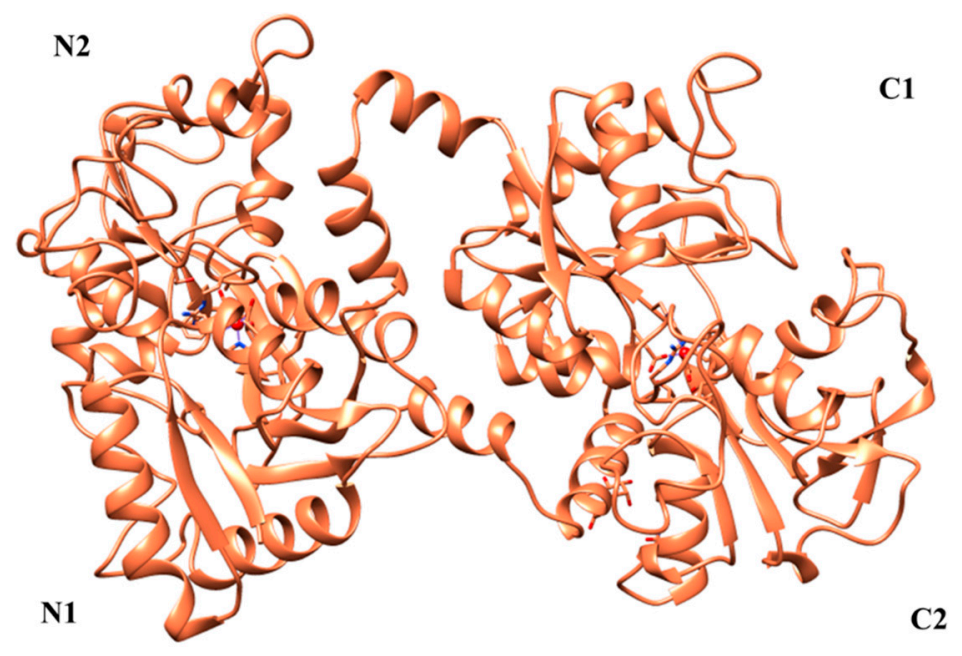

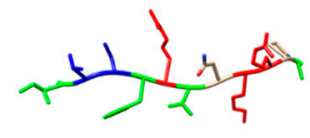

Lf(1-11)

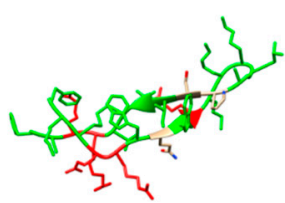

Lfcin

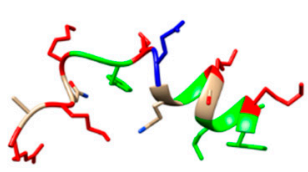

Lfampin

Figure 1. Three-dimensional structures of holo-bLf (PDB ID:1BLF), Lf(1-11), Lfcin (PDB ID: 1LFC), and Lfampin (PDB ID: 2MD1). N1, N2, C1, and C2 indicate the subdomains of each lobe. The iron atom is shown as a red sphere, while the interacting amino acid residues of Lf are highlighted. Lf(1-11) is shown with the conformation it has in the intact protein (i.e., bovine lactoferrin) and the missing residues have been added with MODELLER-9.15 [24]. The colors of peptides indicate aminoacid properties: Green: hydrophobic; Blue: negatively charged; Red: positively charged; White: polar. For details, see text. The pictures were drawn by UCSF-Chimera package [25].

A hinge region containing parts of an $\alpha$-helix connects the two lobes. In hLf, the polypeptide chain includes amino acids 1-332 for the $\mathrm{N}$ lobe and 344-703 for the $\mathrm{C}$ lobe and it is made up of $\alpha$-helix and $\beta$-sheet structures. Each lobe can be further divided into two subdomains (N1 and N2 in the $\mathrm{N}$-lobe and $\mathrm{C} 1$ and $\mathrm{C} 2$ in the C-lobe) forming two clefts for each lobe, inside of which the iron is bound [23]. In hLf, the subdomain N1 contains the residues 1-90 and 251-333, while N2 contains the residues $91-250)[10,20,23]$. Each iron ion is bound to the protein together with two carbonate ions $\left(\mathrm{CO}_{3}{ }^{2-}\right)$ whose protonation leads to iron binding weaknesses [20,26]. However, the binding site is not strictly restricted to iron, since $\mathrm{Lf}$ is able to bind other metals such as $\mathrm{Cu}^{2+}, \mathrm{Zn}^{2+}$ and $\mathrm{Mn}^{2+}$ ions [27-29]. In biological fluids, Lf can be found either without bound iron (apo-lactoferrin) or in iron-bound form (holo-lactoferrin) [30].

A large number of studies have demonstrated its tolerance in humans, and bLf has been approved by FDA (US) and European Food Safety Authority as a dietary supplement in food products [31,32]. However, as Lf is susceptible to peptic digestion in the stomach, it cannot easily access to the digestive tract. To overcome this problem and to improve the therapeutic potential of Lf, the use of microparticles or liposomes has been tested [33]. Liposomalization increased the Lf action by the improvement of stability against gastric degradation and facilitated the interaction with the intestinal membrane and with Lf-specific receptors [33,34]. 


\section{Lactoferrin's Antimicrobial Activity}

Lf's protection against microbial infection was the first activity discovered and it is currently the most widely studied function to date [4-11]. There is a huge amount of literature data describing the in vitro and in vivo efficacy and animal-model benefits of Lf. The antimicrobial activity of Lf is due to two different mechanisms. Its primary role is to sequester free iron, thus removing an essential substrate required for bacterial growth and exerting a bacteriostatic effect. The other mechanism involves a direct interaction of the Lf with the infectious agent. Lf binds to the lipopolysaccharide of bacterial walls, and may also damage bacteria via formation of peroxides catalyzed by Lf-bound iron (III) ions, affecting membrane permeability and resulting in bacterial cell lysis [19,35,36]. Since the pioneristic work of Bullen and co-workers [37] on the protective effect of Lf towards E. coli 0111 infection in newborn guinea-pigs, there are several experimental observations that oral administration of Lf reduces bacterial and fungal infections mainly in the gastro-intestinal tract (see, for example, [9,38-44]).

On the other hand, Lf promotes the growth of bacteria with low iron requirements such as Lactobacillus and Bifidobacteria, which are generally believed to be beneficial to the host [45]. Orally administered recombinant human Lf (rhLf) was indeed demonstrated to be able to modulate the intestinal flora in piglets [46]. Recently oral administration of bLf has had a significant increase of interest because of the demonstration of its probiotic activity both in adults and in infants, including prematurely born [47-49].

In addition to this well-known antibacterial function, Lf displays a potent antiviral activity of against both enveloped and naked viruses, like Cytomegalovirus (CMV) [50,51], Herpes simplex virus (HSV) [9,52-54], Human immunodeficiency virus (HIV) [55-57], Human hepatitis C (HCV) and human hepatitis $B(\mathrm{HBV})$ viruses [58,59]. Therefore, the effects of Lf oral administration have been studied in several bacterial and viral infections in animals and humans and the beneficial effects of orally administered Lf have recently been found in viral infections including the common cold, influenza, and viral gastroenteritis [60-63].

An antiparasitic activity of Lf has been also demonstrated. This antiparasitic activity appears to involve interference with iron acquisition in some parasites, e.g., Pneumocystis carinii [64,65], on the other hand, Lf appears to act as a specific iron donor in other parasites such as Tritrichomonas foetus [66]. Furthermore, Lf is able to inhibit the growth of Plasmodium berghei, binding directly to the plasmodial CS protein [67]. Moreover, Lf has in vitro activity towards human pathogenic fungi, such as Candida albicans and several other Candida species [11,68].

\section{Nutraceutical and Immunomodulation Protective Effects}

Over the past decade, Lf has been reported to affect various immunological functions playing an important role in host defence against infection and excessive inflammation, appearing as a key element in the mammalian immune system [69]. Indeed, Lf appears to be able to both upand down-regulate the endogenous inflammatory response, possessing pro- and anti-inflammatory properties [70]. The cellular and molecular mechanisms responsible for the immunomodulatory effects of Lf, are not fully elucidated, and in vitro and in vivo studies suggest the existence of multiple mechanisms [71-74]. Lf acts on B-cells, which are well-known antigen presenters, to allow their subsequent interaction with $\mathrm{T}$ cells, which promotes elevation of the antibody response [75] by promoting the maturation of T-cell precursors into competent helper cells and by the differentiation of immature B-cells into efficient antigen presenting cells [72]. Both bovine and human Lf are able to bind surface receptors on the human T-cell line (Jurkat cell line) [76] and the expression of Lf receptors has been recently reported in all T-cell subsets [77]. At the cellular level, Lf modulates the migration, maturation and function of immune cells [78]. There are also suggestions that Lf can play a role in the initiation of T-cell activation through the modulation of dendritic cell function [79]. Several studies (mostly on animals but also on humans) have focused on the immunomodulatory effects of orally administered Lf: 
- Mulder et al. [80] found that oral administration of bLf to healthy human males increased the activation of total T-cell, helper T-cell and cytotoxic T-cell, increasing also hydrophilic antioxidant capacity (reviewed by Mayeur et al. in 2016 [81]).

- Saraiva et al. [82] fed piglets with $3.6 \mathrm{~g} / \mathrm{L}$ of bLF and showed higher IgG concentrations in serum and more IL-10, an immunomodulatory cytokine potentially limiting inflammation, was secreted by spleen cells into the culture media;

- Liu et al. [83] administering orally bLf to piglets, and found an increase of the blood NK cell populations and NK Lf receptor expression without affecting NK cell cytotoxicity, suggesting that Lf could help protect the organism of infants from infections;

- Cooper et al. [84] fed young pigs with transgenic cows' milk containing rhLf. They showed favorable changes in systemic health in rhLf-milk fed pigs that had beneficial changes in circulating leukocyte populations with a decrease in neutrophils and increase in lymphocytes which is an indicator of decreased systemic inflammation. Moreover, favorable changes in intestinal villi architecture were also observed both in the duodenum and in the ileum of rhLf-milk fed pigs;

- Yang et al. [85] showed that the percentage of piglets with symptoms of diarrhea during the first 38 days of life was decreased, if compared with the control group, from $54 \%$ to $15 \%$ by orally administered Lf at a dose level of 155 and $285 \mathrm{mg} / \mathrm{kg} /$ day, respectively. A significant delay in the onset of diarrhea by at least 1 week in the higher Lf dose group and 4 days in the lower Lf dose group, compared with the control group of piglets, was also observed;

- Wu et al. [86] investigated the effect of enteral bLf supplementation on intestinal adaptation and barrier function in a rat model of short bowel syndrome (SBS) and they demonstrated a protective effect of Lf due to small-bowel luminal sIgA and TJ protein expression upregulation together with reduced intestinal permeability, supporting intestinal barrier integrity and providing better protection against bacterial infections;

- Arciniega-Martınez et al. [87] analyzed the effects of bLf orally administered to healthy male $\mathrm{BALB} / \mathrm{c}$ mice. They found that antibodies, antibody-secreting cells, and B and T responses in both Peyer's patches and in lamina propria were higher in bLf-treated than bLf-untreated mice, suggesting a potential application of bLf as a nutraceutical to control inflammation in the distal small intestine;

- Kawashima et al. [88] demonstrated the protective effect of Lf towards "Dry Eye Syndrome" caused by age-induced decrease in lacrimal gland secretory function. They attributed this activity to Lf anti-inflammatory properties since oral administration to aged mice of Lf alone or in combination with other antioxidants resulted in decreasing inflammatory cell infiltration in eyes. On the other hand [89] they demonstrated also that Lactoferrin administration decreases MCP-1 and TNF- $\alpha$ expression levels and markers for oxidative damage while increases the volume of tear secretion. Moreover, a combined dietary supplement containing fish oil, lactoferrin, zinc, vitamin C, lutein, vitamin E, $\gamma$-aminobutanoic acid, and Enterococcus faecium WB2000 improves the symptoms of dry eye syndrome with no side effects [90].

However, despite the abundant evidence that orally administered Lf indeed has direct and indirect effects against inflammation, up to now it was not possible to understand the mechanisms of action of Lf that appear to be controversial in a lot of cases. In addition, several approaches have been used to study the way in which lactoferrin mediates neonatal immune development. One of these was to create transgenic animals that overexpress Lf in milk, which has been done in mice, goats, and cows as reviewed by Cooper et al. [91].

\section{Anticancer Activity of Orally Administered Lactoferrin}

The process of carcinogenesis includes the initial occurrence of genetic alterations which can lead to the inactivation of tumor suppressor genes and further accumulation of genetic alterations during 
tumor progression [91]. Silencing or downregulation of the lactoferrin gene in cells is usually related to the occurrence of certain diseases, especially carcinomas $[92,93]$.

Table 1. Anticancer activities of lactoferrin and lactoferricin.

\begin{tabular}{|c|c|c|}
\hline Cancer Type & Mechanism of Anticancer Action & References \\
\hline Breast & $\begin{array}{l}\text { hLf causes arrest in the G0/G1 phase, induction of cell apoptosis and regulation } \\
\text { of the expression of } \mathrm{Bcl}-2 \text {, Bax and activation of caspase } 3 \text {. }\end{array}$ & [94] \\
\hline \multirow[t]{2}{*}{ Cervix } & $\begin{array}{l}\text { hLf inhibits cervical cancer due to elevated expression of Fas and decreased the } \\
\text { ratio of anti- to pro-apoptotic molecule Bcl-2/Bax. }\end{array}$ & [95] \\
\hline & $\begin{array}{l}\text { Lfcin causes arrest in the at S phase through downregulation of cyclin E1 in } \\
\mathrm{CaCO}_{2} \text { cells. }\end{array}$ & [96] \\
\hline \multirow[t]{3}{*}{ Colon } & $\begin{array}{l}\text { hLF increases expression of TGF- } \beta 1 \text {, and holo-forms of LFs stimulate IL-18 } \\
\text { secretion in } \mathrm{CaCO}_{2} \text { cells. }\end{array}$ & [97] \\
\hline & Lf induces caspase- 1 and IL-18. & [98] \\
\hline & bLf increases production of CD4+, CD8+, and IL-18 & [99] \\
\hline \multirow[t]{2}{*}{ Gastric } & $\begin{array}{l}\text { BLfcin induces apoptosis human gastric cancer cell line AGS. } \\
\text { Lf induces suppression of AKT signaling via inhibition of }\end{array}$ & [100] \\
\hline & $\begin{array}{l}\text { 3-phosphoinositide-dependent protein kinase-1 expression and/or blocking of } \\
\text { the K18-14-3-3 complex. } \\
\text { bLf and [Polyphenon-B (P-B)] P-B was more effective in inhibiting hamster }\end{array}$ & [101] \\
\hline \multirow[t]{5}{*}{$\begin{array}{l}\text { Head, neck, } \\
\text { and oral }\end{array}$} & $\begin{array}{l}\text { buccal pouch (HBP) carcinogenesis by inhibiting oxidative DNA damage, } \\
\text { carcinogen activation, cell proliferation, invasion, and angiogenesis. }\end{array}$ & [102] \\
\hline & Lf inhibits tumor through direct cellular inhibition and immunomodulation. & [103] \\
\hline & & [104] \\
\hline & $\begin{array}{l}\text { Lf derivated peptides induce apoptosis via JNK/SAPK activation in squamous } \\
\text { cell carcinoma cell line SAS. }\end{array}$ & [105] \\
\hline & $\begin{array}{l}\text { LfcinB6 (RRWQWR) induces citoxicity via caspase-mediated and cathepsin } \\
\text { B-mediated mechanism in T-leukemia cells. }\end{array}$ & [106] \\
\hline \multirow[t]{4}{*}{ Leukemia } & $\begin{array}{l}\text { Lfcin kills T-leukemia cells by triggering the mitochondrial pathway of apoptosis } \\
\text { and through the generation of reactive oxygen species. }\end{array}$ & [107] \\
\hline & $\begin{array}{l}\text { LF11-322 (PFWRIRIRR-NH2), peptide fragment derived from human } \\
\text { lactoferricin, induces necrosis in leukemia cells (MEL and HL-60 leukemia cells). }\end{array}$ & [108] \\
\hline & $\begin{array}{l}\text { Lf increases CDK6 and hyper-phosphorylated retinoblastoma protein, resulting } \\
\text { in the induction of E2F1-dependent apoptosis in Jurkat human leukemia T } \\
\text { lymphocytes. }\end{array}$ & [109] \\
\hline & $\begin{array}{l}\text { bLf inhibits NNK-induced mouse lung tumorigenesis, through the modification } \\
\text { of cell proliferation and/or apoptosis. }\end{array}$ & [110] \\
\hline \multirow[t]{3}{*}{ Lung } & $\begin{array}{l}\text { hLf inhibits the growth of head and neck squamous cell carcinoma via direct } \\
\text { cellular inhibition as well as systemically via immunomodulation. }\end{array}$ & [103] \\
\hline & Lf shows antiproliferative effects via hypophosphorylation of Rb on H1299 cells. & [111] \\
\hline & $\begin{array}{l}\text { Lfcin inhibits VEGF expression and induces apoptosis on non-small cell lung } \\
\text { cancer H460. }\end{array}$ & [112] \\
\hline \multirow{3}{*}{ NCS } & $\begin{array}{l}\text { Lfcin inhibits tumor growth and induces apoptosis through activation of } \\
\text { caspases in neuroblastoma cells and in vivo). }\end{array}$ & [113] \\
\hline & Lf causes growth inhibition in the NMD and FN primary cell lines and in the & \\
\hline & $\begin{array}{l}\text { U87MG continuous cell line (downregulation of cyclin D1 and D4). } \\
\text { Administration of hLf with TMZ enhanced the effect of chemotherapy both } \\
\text { in vitro and in vivo. }\end{array}$ & [114] \\
\hline
\end{tabular}

Table 1 summarizes the identified anticancer activities of Lf and its derivative peptides, among which the lactoferricin (Lfcin) (see paragraph Lactoferrin peptides). Lf, and subsequently its peptides, is one of the most studied nutraceutical proteins, showing considerable potential for preventing the different stages of cancer, including initiation, promotion, and progression. Usually, alterations of the lactoferrin gene in cells are associated with an increased incidence of cancer. Several studies suggest that exogenous treatment with Lf and its derivatives can efficiently inhibit the growth of tumors and reduces susceptibility to cancer $[115,116]$. The effect of apo- and holo-Lf in inhibiting tumor development and reducing growth and metastasis of solid tumors was also observed by Kanwar et al. and Tsuda et al. [117-119].

Actually, Lf and its derivatives can be an effective anti-cancer treatment if combined with other therapeutic agents or if encapsulated in carriers after appropriate modifications. It is interesting 
to note that some studies have already begun to use these approaches to increase the cytotoxic effects of Lf and its derivatives [120-124]. Oral Lf accelerated reconstitution of humoral and cellular immune responses during chemotherapy- induced immunosuppression in mice, suggesting it could be employed to overcome tamoxifen-induced immune suppression $[116,117]$ and indeed, Kanwar and coworwers showed that the oral administration of holo-bLf could improve the chemotherapeutic effects of tamoxifen in the treatment of ER-negative breast cancers [117]. Orally administered holo-bLf improves the chemotherapeutic effects of tamoxifen in the treatment of basal-like breast cancer in mice inducing significantly higher cancer cell death (apoptosis) and cytotoxicity in a dose-dependent manner in cancer cells than the normal intestinal cells [125].

As combination therapy becomes increasingly popular, it is likely that Lf will continue to be studied for its potential value as a primary or adjuvant agent in the treatment of cancer [12]. Clinical trials involving the use of this protein in cancer therapy are ongoing and the relatively low cytotoxicity of Lf and its derivatives as compared with known anticancer drugs, along with the lack of data about the mechanisms of action, is likely to encourage the clinical use of Lf in cancer treatment.

\section{Other Lactoferrin Activities}

In addition, there is a potential use of Lf for the improvement of bone health. Dietary Lf supplementation preserved bone mass and microarchitecture in ovariectomized rats, improving both bone mineral density and bone strength [126]. More importantly, in 38 healthy postmenopausal women, milk ribonuclease-enriched lactoferrin induces positive effects on bone turnover markers [127]. Lf appeared therefore to be a promising candidate for the development of an anabolic therapeutic factor for osteoporosis [128], even though no more recent information is present in scientific literature.

Maternal iron-bLf supplementation stimulates human fetal growth in normal pregnancy [129]. In addition, iron-bLf administration is able to decrease the onset of dexamethasone (DEX) induced IntraUterine Growth Restriction (IUGR) that alters levels of brain metabolites ( $\gamma$-aminobutyric acid, glutamate, $N$-acetylaspartate, and $N$-acetylaspartylglutamate) and transcripts (brain-derived neurotrophic factor (BDNF), divalent metal transporter 1 (DMT-1), and glutamate receptors), leading to defective hippocampal development and later cognitive impairment [130].

\section{Lactoferrin Peptides}

An increasing number of functions are associated with the peptides of this protein. These peptides are produced by the action of proteolytic enzymes, and could be produced in the intestinal lumen after Lf oral ingestion. In particular, three peptides have been especially studied. They originate from the $\mathrm{N}$-lobe of Lf, and have an antimicrobial activity by their hydrophobicity, cationic charge, and helical conformation, which render these peptides amphiphilic molecules.

These three peptides are $\operatorname{Lf}(1-11)$, Lfcin and lactoferrampin (Lfampin). In detail, $\operatorname{Lf}(1-11)$ is the oligopeptide that includes the first eleven aminoacidic residues of the Lf. The presence of the hydrophobic and hydrophilic residues lends to it a highly cationic nature. It has been demonstrated that $\operatorname{Lf}(1-11)$ interacts with the membrane of several bacteria.

Lfcin is an amphipathic, cationic peptide with anti-microbial and anti-cancer properties. Indeed it is the most studied anti-microbial peptide derived from milk proteins. It can be generated by the pepsin-mediated digestion of Lf (aminoacid residues 17-41). The peptide has an abundance of basic aminoacids including Lys and Arg, as well as hydrophobic residues like tryptophan and phenylalanine. Lfcin has several biological activities including antiviral, antibacterial, antifungal and anti-inflammatory activities.

Lfampin comprises residues 268-284 in the N1 domain of Lf, and was found to be located in closed proximity to Lfcin. Lfampin exhibits broad antimicrobial action against several Gram-positive and Gram-negative bacteria, yeast and parasites.

Lf- derived peptides showed often a considerably higher antimicrobial activity than the native protein with broad antibacterial spectrum and low minimum concentration [131]. However, their 
activities are not limited to the antimicrobial properties but several protective activities have been found in Lf- derived peptides. These activities are summarized in Table 2.

Table 2. Biological activities of lactoferrin peptides.

\begin{tabular}{|c|c|c|}
\hline Activity & Peptide & References \\
\hline \multirow{5}{*}{ Gram positive } & $\operatorname{Lf}(1-11)$ & [132] \\
\hline & Lfcin & [133-135] \\
\hline & Lfampin & [134] \\
\hline & $\operatorname{Lf}(1-11)$ & [136] \\
\hline & Lfcin & [137-139] \\
\hline & Lfampin & [140-142] \\
\hline \multirow{4}{*}{ Antiviral } & $\operatorname{Lf}(1-11)$ & [143] \\
\hline & Lfcin & {$[54,144-147]$} \\
\hline & Lfampin & [143] \\
\hline & $\operatorname{Lf}(1-11)$ & [148] \\
\hline \multirow[t]{2}{*}{ Antifungal } & Lfcin & {$[149,150]$} \\
\hline & Lfampin & {$[151,152]$} \\
\hline \multirow{2}{*}{ Antiparasitic } & Lfcin & [153] \\
\hline & Lfampin & [154] \\
\hline Anticancer & Lfcin & [155-158] \\
\hline
\end{tabular}

\section{Conclusions}

Lf has been studied since long time for its various protective activities for which the protein has been evolved in a wide range of animals, including humans. The most beneficial activities are those related to the antimicrobial, antinflammatory and anticancer properties of the protein and of its peptides that may be possibly generated after ingestion. In addition, there is growing evidence of specific immunomodulatory activity of Lf in adults and newborns where, beyond the well-known nutritional immunity, Lf is of particular importance for the development of the immune system. These activities were shown after oral administration of bovine and human Lf and, together with its probiotic effect and the lack of any specific toxicity, allow Lf to be an ideal nutraceutical example.

Acknowledgments: This work has been partially supported by a Grant from Ministero della Salute of Italy to LL. PROGETTO RICERCA FINALIZZATA-GIOVANI RICERCATORI 2012 (Development of a rapid, fast and low-cost analytical kit to evaluate quality and safety of milk and dairy products: GR-2011-02348227).

Conflicts of Interest: The authors declare no conflict of interest.

\section{References}

1. Sorensen, M.; Sorensen, S.P.L. The proteins in whey. Comptes-rendus des Trav. du Lab. Carlsberg 1939, 23, 55-99.

2. Groves, M.L. The isolation of a red protein from milk. J. Am. Chem. Soc. 1960, 82, 3345-3350. [CrossRef]

3. González-Chávez, S.A.; Arévalo-Gallegos, S.; Rascón-Cruz, Q. Lactoferrin: Structure, function and applications. Int. J. Antimicrob. Agents 2009, 33, 301.e1-301.e8. [CrossRef] [PubMed]

4. Sánchez, L.; Calvo, M.; Brock, J.H. Biological role of lactoferrin. Arch. Dis. Child. 1992, 67, 657-661. [CrossRef] [PubMed]

5. Brock, J. Lactoferrin: A multifunctional immunoregulatory protein? Immunol. Today 1995, 16, 417-419. [CrossRef]

6. Lönnerdal, B.; Iyer, S. Lactoferrin: Molecular structure and biological function. Annu. Rev. Nutr. 1995, 15, 93-110. [CrossRef] [PubMed]

7. Vorland, L.H. Lactoferrin: A multifunctional glycoprotein. APMIS 1999, 107, 971-981. [CrossRef] [PubMed]

8. Brock, J.H. The physiology of lactoferrin. Biochem. Cell Biol. 2002, 80, 1-6. [CrossRef] [PubMed]

9. Valenti, P.; Antonini, G. Lactoferrin: An important host defence against microbial and viral attack. Cell Mol. Life Sci. 2005, 62, 2576-2587. [CrossRef] [PubMed]

10. Baker, E.N.; Baker, H.M. A structural framework for understanding the multifunctional character of lactoferrin. Biochimie 2009, 91, 3-10. [CrossRef] [PubMed] 
11. Leboffe, L.; Giansanti, F.; Antonini, G. Antifungal and antiparasitic activities of lactoferrin. Anti-Infect. Agents Med. Chem. 2009, 8, 114-127. [CrossRef]

12. Zhang, Y.; Lima, C.F.; Rodrigues, L.R. Anticancer effects of lactoferrin: Underlying mechanisms and future trends in cancer therapy. Nutr. Rev. 2014, 72, 763-773. [CrossRef] [PubMed]

13. Giansanti, F.; Leboffe, L.; Angelucci, F.; Antonini, G. The nutraceutical properties of ovotransferrin and its potential utilization as a functional food. Nutrients 2015, 7, 9105-9115. [CrossRef] [PubMed]

14. Giansanti, F.; Leboffe, L.; Pitari, G.; Ippoliti, R.; Antonini, G. Physiolgical roles of ovotransferrin. Biochim. Biophys. Acta Gen. Subj. 2012, 1820, 218-225. [CrossRef] [PubMed]

15. Connely, O.M. Antiinflammatory activities of lactoferrin. J. Am. Coll. Nutr. 2001, 20, 389S-395S. [CrossRef]

16. Rodriguez, D.A.; Vazquez, L.; Ramos, G. Antimicrobial mechanisms and potential clinical application of lactoferrin. Rev. Latino. Microbiol. 2005, 47, 102-111.

17. Van der Strate, B.W.; Beljaars, L.; Molema, G.; Harmsen, M.C.; Meijer, D.K. Antiviral activities of lactoferrin. Antivir. Res. 2001, 52, 225-239. [CrossRef]

18. Öztas, Y.E.R.; Özgünes, N. Lactoferrin: A multifunctional protein. Adv. Mol. Med. 2005, 1, 149-154.

19. Bennett, R.M.; Kokocinski, T. Lactoferrin content of peripheral blood cells. Br. J. Haematol. 2005, 39, 509-521. [CrossRef]

20. Anderson, B.F.; Baker, H.M.; Dodson, E.J.; Norris, G.E.; Rumball, S.V.; Waters, J.M.; Baker, E.N. Structure of human lactoferrin at 3.2-Å resolution. Proc. Natl. Acad. Sci. USA 1987, 84, 1769-1773. [CrossRef] [PubMed]

21. Anderson, B.F.; Baker, H.M.; Norris, G.E.; Rice, D.W.; Baker, E.N. Structure of human lactoferrin: Crystallographic structure analysis and refinement at $2.8 \AA$ resolution. J. Mol. Biol. 1989, 209, 711-734. [CrossRef]

22. Baker, E.N. Structure and reactivity of transferrins. Adv. Inorg. Chem. 1994, 41, 389-463.

23. Moore, S.A.; Anderson, B.F.; Groom, C.R.; Haridas, M.; Baker, E.N. Threedimensional structure of diferric bovine lactoferrin at $2.8 \AA$ resolution. J. Mol. Biol. 1997, 274, 222-236. [CrossRef] [PubMed]

24. Eswar, N.; Webb, B.; Marti-Renom, M.A.; Madhusudhan, M.S.; Eramian, D.; Shen, M.Y.; Pieper, U.; Sali, A. Comparative protein structure modeling using MODELLER. Curr. Protoc. Bioinform. 2006, 8, 5-6.

25. Pettersen, E.F.; Goddard, T.D.; Huang, C.C.; Couch, G.S.; Greenblatt, D.M.; Meng, E.C.; Ferrin, T.E. UCSF Chimera-A visualization system for exploratory research and analysis. J. Comput. Chem. 2004, 25, 1605-1612. [CrossRef] [PubMed]

26. Rastogi, N.; Singh, A.; Singh, P.K.; Tyagi, T.K.; Pandey, S.; Shin, K.; Kaur, P.; Sharma, S.; Singh, T.P. Structure of iron saturated C-lobe of bovine lactoferrin at $\mathrm{pH} 6.8$ indicates a weakening of iron coordination. Proteins: Struct. Funct. Bioinform. 2016, 84, 591-599. [CrossRef] [PubMed]

27. Aisen, P.; Harris, D.C. Physical biochemistry of the transferrins. In Iron Carriers and Iron Proteins; Loehr, T., Ed.; VCH: New York, NY, USA, 1989; pp. 241-351.

28. Baker, E.N.; Anderson, B.F.; Baker, H.M.; Day, C.L.; Haridas, M.; Norris, G.E.; Rumball, S.V.; Smith, C.A.; Thomas, D.H. Three-dimensional structure of lactoferrin in various functional states. Adv. Exp. Med. Biol. 1994, 357, 1-12. [PubMed]

29. Baker, E.N.; Baker, H.M. Molecular structure, binding properties and dynamics of lactoferrin. Cell Mol. Life Sci. 2005, 62, 2531-2539. [CrossRef] [PubMed]

30. Baker, H.M.; Baker, E.N. A structural perspective on lactoferrin function. Biochem. Cell Biol. 2012, 90, 320-328. [CrossRef] [PubMed]

31. Rulis, A.M. Agency Response Letter GRAS Notice No. GRN 000077. Available online: http:// www.fda.gov/Food/IngredientsPackagingLabeling/GRAS/NoticeInventory/ucm154188.htm (accessed on 21 September 2016).

32. EFSA. Panel on Dietetic Products, Nutrition and Allergies (NDA). Scientific Opinion on bovine lactoferrin. EFSA J. 2012, 10, 2811. [CrossRef]

33. Onishi, H. Lactoferrin delivery systems: Approaches for its more effective use. Expert. Opin. Drug Deliv. 2011, 8, 1469-1479. [CrossRef] [PubMed]

34. Akiyama, Y.; Oshima, K.; Kuhara, T.; Shin, K.; Abe, F.; Iwatsuki, K.; Nadano, D.; Matsuda, T. A lactoferrin-receptor, intelectin 1, affects uptake, sub-cellular localization and release of immunochemically detectable lactoferrin by intestinal epithelial Caco-2 cells. J. Biochem. 2013, 154, 437-448. [CrossRef] [PubMed]

35. Bullen, J.J. The significance of iron in infection. Rev. Infect. Dis. 1981, 3, 1127-1138. [CrossRef] [PubMed] 
36. Braun, V.; Braun, M. Active transport of iron and siderophore antibiotics. Curr. Opin. Microbiol. 2002, 5, 194-201. [CrossRef]

37. Bullen, J.J. Iron-binding proteins in milk and resistance to Escherichia coli infection in infants. Proc. R. Soc. Med. 1972, 65, 1086. [CrossRef] [PubMed]

38. Weinberg, E.D. Human lactoferrin: A novel therapeutic with broad spectrumpotential. J. Pharm. Pharmacol. 2001, 53, 1303-1310. [CrossRef] [PubMed]

39. Tomita, M.; Wakabayashi, H.; Yamauchi, K.; Teraguchi, S.; Hayasawa, H. Bovine lactoferrin and lactoferricin derived from milk: Production and applications. Biochem. Cell Biol. 2002, 80, 109-112. [CrossRef] [PubMed]

40. Teraguchi, S.; Wakabayashi, H.; Kuwata, H.; Yamauchi, K.; Tamura, Y. Protection against infections by oral lactoferrin: Evaluation in animal models. Biometals 2004, 17, 231-234. [CrossRef] [PubMed]

41. Di Mario, F.; Aragona, G.; Dal Bò, N.; Cavestro, G.M.; Cavallaro, L.; Iori, V.; Comparato, G.; Leandro, G.; Pilotto, A.; Franzè, A. Use of bovine lactoferrin for helicobacter pylori eradication. Dig. Liver Dis. 2003, 35, 706-710. [CrossRef]

42. Yekta, M.A.; Cox, E.; Goddeeris, B.M.; Vanrompay, D. Reduction of Escherichia coli O157: H7 excretion in sheep by oral lactoferrin administration. Vet. Microbiol. 2011, 150, 373-378. [CrossRef] [PubMed]

43. Welsh, K.J.; Hwang, S.A.; Boyd, S.; Kruzel, M.L.; Hunter, R.L.; Actor, J.K. Influence of oral lactoferrin on Mycobacterium tuberculosis induced immunopathology. Tuberculosis 2011, 91, S105-S113. [CrossRef] [PubMed]

44. Velliyagounder, K.; Alsaedi, W.; Alabdulmohsen, W.; Markowitz, K.; Fine, D.H. Oral lactoferrin protects against experimental candidiasis in mice. J. Appl. Microbiol. 2015, 118, 212-221. [CrossRef] [PubMed]

45. Sherman, M.P.; Bennett, S.H.; Hwang, F.F.; Yu, C. Neonatal small bowel epithelia: Enhancing anti-bacterial defense with lactoferrin and Lactobacillus GG. Biometals 2004, 17, 285-289. [CrossRef] [PubMed]

46. Hu, W.; Zhao, J.; Wang, J.; Yu, T.; Wang, J.; Li, N. Transgenic milk containing recombinant human lactoferrin modulates the intestinal flora in piglets. Biochem. Cell Biol. 2012, 90, 485-496. [CrossRef] [PubMed]

47. Sachdeva, A.; Rawat, S.; Nagpal, J. Efficacy of fermented milk and whey proteins in Helicobacter pylori eradication: A review. World J. Gastroenterol. 2014, 20, 724-737. [CrossRef] [PubMed]

48. Vongbhavit, K.; Underwood, M.A. Prevention of necrotizing enterocolitis through manipulation of the intestinal microbiota of the premature Infant. Clin. Ther. 2016, 38, 716-732. [CrossRef] [PubMed]

49. Pammi, M.; Abrams, S.A. Oral lactoferrin for the treatment of sepsis and necrotizing enterocolitis in neonates. Cochrane Database Syst. Rev. 2011, 10, CD007138. [CrossRef] [PubMed]

50. Harmsen, M.C.; Swart, P.J.; de Béthune, M.P.; Pawels, R.; De Clercq, E.; The, T.H.; Meijer, D.K.F. Antiviral effects of plasma and milk proteins: Lactoferrin shows a potent activity against both human immunodeficiency virus and human cytomegalovirus replication in vitro. J. Infect. Dis. 1995, 172, 280-388. [CrossRef]

51. Andersen, J.H.; Osbakk, S.A.; Vorland, L.H.; Traavik, T.; Gutteberg, T.J. Lactoferrin and cyclic lactoferricin inhibit the entry of human cytomegalovirus into human fibroblasts. Antivir. Res. 2001, 51, 141-149. [CrossRef]

52. Marchetti, M.; Longhi, C.; Conte, M.P.; Pisani, S.; Valenti, P.; Seganti, L. Lactoferrin inhibits herpes simplex virus type 1 adsorption to Vero cells. Ativir. Res. 1996, 29, 221-231. [CrossRef]

53. Marchetti, M.; Pisani, S.; Antonini, G.; Valenti, P.; Seganti, L.; Orsi, N. Metal complexes of bovine lactoferrin inhibit in vitro replication of herpes simplex virus type 1 and 2. Biometals 1998, 11, 89-94. [CrossRef] [PubMed]

54. Siciliano, R.; Rega, B.; Marchetti, M.; Seganti, L.; Antonini, G.; Valenti, P. Bovine lactoferrin peptidic fragments involved in inhibition of herpes simplex virus type 1 infection. Biochem. Biophys. Res. Commun. 1999, 264, 19-23. [CrossRef] [PubMed]

55. Swart, P.J.; Kuipers, M.E.; Smith, C.; Pawels, R.; de Béthune, M.P.; De Clerck, E.; Meijer, D.K.F.; Huisman, J.G. Antiviral effects of milk proteins: Acylation results in polyanionic compounds with potent activity against human immunodeficiency virus types 1 and 2 in vitro. AIDS Res. Human Retrov. 1996, 12, 769-775. [CrossRef] [PubMed]

56. Puddu, P.; Borghi, P.; Gessani, S.; Valenti, P.; Belardelli, F.; Seganti, L. Antiviral effects of bovine lactoferrin saturated with metal ions on early steps of human immunodeficiency virus type 1 infection. Int. J. Biochem. Cell Biol. 1998, 30, 1055-1062. [CrossRef]

57. Berkhout, B.; Floris, R.; Recio, I.; Visser, S. The antiviral activity of the milk protein lactoferrin against the human immunodeficiency virus type 1. Biometals 2004, 17, 291-294. [CrossRef] [PubMed] 
58. Ikeda, M.; Sugiyama, K.; Tanaka, T.; Tanaka, K.; Sekihara, H.; Shimotohno, K.; Kato, N. Lactoferrin markedly inhibits hepatitis $C$ virus infection in cultured human hepatocytes. Biochem. Biophys. Res. Commun. 1998, 245, 549-553. [CrossRef] [PubMed]

59. Hara, K.; Ikeda, M.; Saito, S.; Matsumoto, S.; Numata, K.; Kato, N. Lactoferrin inhibits hepatitis B virus infection in cultured human hepatocytes. Hepatol. Res. 2002, 24, 228-236. [CrossRef]

60. Tanaka, K.; Ikeda, M.; Nozaki, A.; Kato, N.; Tsuda, H.; Saito, S.; Sekihara, H. Lactoferrin inhibits hepatitis C virus viremia in patients with chronic hepatitis C: A pilot study. Jpn. J. Cancer Res. 1999, 90, 367-371. [CrossRef] [PubMed]

61. Ueno, H.; Sato, T.; Yamamoto, S.; Tanaka, K.; Ohkawa, S.; Takagi, H.; Yokosuka, O.; Furuse, J.; Saito, H.; Sawaki, A.; et al. Randomized, double-blind, placebo-controlled trial of bovine lactoferrin in patients with chronic hepatitis C. Cancer Sci. 2006, 97, 1105-1110. [CrossRef] [PubMed]

62. Pietrantoni, A.; Dofrelli, E.; Tinari, A.; Ammendolia, M.G.; Puzelli, S.; Fabiani, C.; Donatelli, I.; Superti, F. Bovine lactoferrin inhibits influenza A virus induced programmed cell death in vitro. Biometals 2010, 23, 465-475. [CrossRef] [PubMed]

63. Wakabayashi, H.; Oda, H.; Yamauchi, K.; Abe, F. Lactoferrin for prevention of common viral infections. J. Infect. Chemother. 2014, 20, 666-671. [CrossRef] [PubMed]

64. Weinberg, G.A. Iron chelators as therapeutic agents against Pneumocystis carinii. Antimicrob. Agents Chemother. 1994, 38, 997-1003. [CrossRef]

65. Cirioni, O.; Giacometti, A.; Barchiesi, F.; Scalise, G. Inhibition of growth of Pneumocystis carinii by lactoferrins alone and in combination with pyrimethamine, clarithromycin and minocycline. J. Antimicrob. Chemother. 2000, 46, 577-582. [CrossRef] [PubMed]

66. Tachezy, J.; Kulda, J.; Bahnikova, I.; Suchan, P.; Razga, J.; Schrevel, J. Tritrichomonas foetus: Iron acquisition from lactoferrin and transferrin. Exp. Parasitol. 1996, 83, 216-228. [CrossRef] [PubMed]

67. Shakibaei, M.; Frevert, U. Dual interaction of the malaria circumsporozoite protein with the low density lipoprotein receptor-related protein (LRP) and heparan sulfate proteoglycans. J. Exp. Med. 1996, 184, 1699-1711. [CrossRef] [PubMed]

68. Giansanti, F.; Leboffe, L.; D’Elia, I.; Antonini, G. An update on the antifungal activities of Lactoferrin: New promising applications in diagnostic, therapeutics and biotechnology. Anti-Infect. Agents 2013, 11, 155-158. [CrossRef]

69. Puddu, P.; Valenti, P.; Gessani, S. Immunomodulatory effects of lactoferrin on antigen presenting cells. Biochimie 2009, 91, 11-18. [CrossRef] [PubMed]

70. Embleton, N.D.; Berrington, J.E.; McGuire, W.; Stewart, C.J.; Cummings, S.P. Lactoferrin: Antimicrobial activity and therapeutic potential. Semin. Fetal Neonat. Med. 2013, 18, 143-149. [CrossRef] [PubMed]

71. Legrand, D.; Mazurier, J. A critical review of the roles of host lactoferrin in immunity. Biometals 2010, 23, 365-376. [CrossRef] [PubMed]

72. Actor, J.K.; Hwang, S.A.; Kruzel, M.L. Lactoferrin as a natural immune modulator. Curr. Pharm. Des. 2009, 15, 1956-1973. [CrossRef] [PubMed]

73. Turin, C.G.; Zea-Vera, A.; Pezo, A.; Cruz, K.; Zegarra, J.; Bellomo, S.; Cam, L.; Llanos, R.; Castañeda, A.; Tucto, L.; et al. Lactoferrin for prevention of neonatal sepsis. Biometals 2014, 27, 1007-1016. [CrossRef] [PubMed]

74. Kruzel, M.L.; Actor, J.K.; Boldogh, I.; Zimecki, M. Lactoferrin in health and disease. Postepy Hig. Med. Dosw. 2007, 61, 261-267.

75. Kawasaki, Y.; Sato, K.; Shinmoto, H.; Dosako, S. Role of basic residues of human lactoferrin in the interaction with B lymphocytes. Biosci. Biotechnol. Biochem. 2000, 64, 14-18. [CrossRef] [PubMed]

76. Dhennin-Duthille, I.; Masson, M.; Damiens, E.; Fillebeen, C.; Spik, G.; Mazurier, J. Lactoferrin upregulates the expression of CD4 antigen through the stimulation of the mitogen- activated protein kinase in the human lymphoblastic T Jurkat cell line. J. Cell. Biochem. 2000, 79, 583-593. [CrossRef]

77. Siqueiros-Cendón, T.; Arévalo-Gallegos, S.; Iglesias-Figueroa, BF.; García-Montoya, IA.; Salazar-Martínez, J.; Rascón-Cruz, Q. Immunomodulatory effects of lactoferrin. Acta Pharmacol. Sin. 2014, 35, 57-66. [CrossRef] [PubMed]

78. Legrand, D.; Elass, E.; Carpentier, M.; Mazurier, J. Lactoferrin: A modulator of immune and inflammatory responses. Cell. Mol. Life Sci. 2005, 62, 2549-2559. [CrossRef] [PubMed] 
79. Hwang, S.A.; Kruzel, M.L.; Actor, J.K. Lactoferrin augments BCG vaccine efficacy to generate T helper response and subsequent protection against challenge with virulent Mycobacterium tuberculosis. Int. Immunopharmacol. 2005, 5, 591-599. [CrossRef] [PubMed]

80. Mulder, A.M.; Connellan, P.A.; Oliver, C.J.; Morris, C.A.; Stevenson, L.M. Bovine lactoferrin supplementation supports immune and antioxidant status in healthy human males. Nutr. Res. 2008, 28, 583-589. [CrossRef] [PubMed]

81. Mayeur, S.; Spahis, S.; Pouliot, Y.; Levy, E. Lactoferrin, a Pleiotropic Protein inHealth and Disease. Antioxid. Redox Signal. 2016, 24, 813-836. [CrossRef] [PubMed]

82. Saraiva, M.; O'Garra, A. The regulation of IL-10 production by immune cells. Nat. Rev. Immunol. 2010, 10, 70-81. [CrossRef] [PubMed]

83. Liu, K.Y.; Comstock, S.S.; Shunk, J.M.; Monaco, M.H.; Donovan, S.M. Natural killer cell populations and cytotoxic activity in pigs fed mother's milk, formula, or formula supplemented with bovine lactoferrin. Pediatr. Res. 2013, 74, 402-407. [CrossRef] [PubMed]

84. Cooper, C.A.; Nelson, K.M.; Maga, E.A.; Murray, J.D. Consumption of transgenic cows' milk containing human lactoferrin results in beneficial changes in the gastrointestinal tract and systemic health of young pigs. Transgenic. Res. 2013, 22, 571-578. [CrossRef] [PubMed]

85. Yang, C.; Zhu, X.; Liu, N.; Chen, Y.; Gan, H.; Troy, F.A.; Wang, B. Lactoferrin up-regulates intestinal gene expression of brain-derived neurotrophic factors BDNF, UCHL1 and alkaline phosphatase activity to alleviate early weaning diarrhea in postnatal piglets. J. Nutr. Biochem. 2014, 25, 834-842. [CrossRef] [PubMed]

86. Wu, J.; Chen, J.; Wu, W.; Shi, J.; Zhong, Y.; van Tol, E.A.F.; Tang, Q.; Cai, W. Enteral supplementation of bovine lactoferrin improves gut barrier function in rats after massive bowel resection. Br. J. Nutr. 2014, 112, 486-492. [CrossRef] [PubMed]

87. Arciniega-Martínez, I.M.; Campos-Rodríguez, R.; Drago-Serrano, M.E.; Sánchez-Torres, L.E.; Cruz-Hernández, T.R.; Reséndiz-Albor, A.A. Modulatory Effects of Oral Bovine Lactoferrin on the IgA Response at Inductor and Effector Sites of Distal Small Intestine from BALB/c Mice. Arch. Immunol. Ther. Exp. (Warsz). 2016, 64, 57-63. [CrossRef] [PubMed]

88. Kawashima, M.; Kawakita, T.; Inaba, T.; Okada, N.; Ito, M.; Shimmura, S.; Watanabe, M.; Shinmura, K.; Tsubota, K. Dietary Lactoferrin Alleviates Age-Related Lacrimal Gland Dysfunction in Mice. PLoS ONE 2012, 7, e33148. [CrossRef]

89. Kawashima, M.; Nakamura, S.; Izuta, Y.; Inoue, S.; Tsubota, K. Dietary Supplementation with a Combination of Lactoferrin, Fish Oil, and Enterococcus faecium WB2000 for Treating Dry Eye: A Rat Model and Human Clinical Study. Ocul. Surf. 2016, 14, 255-263. [CrossRef] [PubMed]

90. Cooper, C.A.; Maga, E.A.; Murray, J.D. Production of human lactoferrin and lysozyme in the milk of transgenic dairy animals: Past, present, and future. Transgenic Res. 2015, 24, 605-614. [CrossRef] [PubMed]

91. de Mejia, E.G.; Dia, V.P. The role of nutraceutical proteins and peptides in apoptosis, angiogenesis, and metastasis of cancer cells. Cancer Metastasis Rev. 2010, 29, 511-528. [CrossRef] [PubMed]

92. Teng, C.; Gladwell, W.; Raphiou, I.; Liu, E. Methylation and expression of the lactoferrin gene in human tissues and cancer cells. Biometals 2004, 17, 317-323. [CrossRef] [PubMed]

93. Shaheduzzaman, S.; Vishwanath, A.; Furusato, B.; Cullen, J.; Chen, Y.; Bañez, L.; Nau, M.; Ravindranath, L.; Kim, K.H.; Mohammed, A.; et al. Silencing of Lactotransferrin expression by methylation in prostate cancer progression. Cancer Biol. Ther. 2007, 6, 1088-1095. [CrossRef] [PubMed]

94. Wang, J.; Li, Q.; Li, K.; Ou, Y.; Han, Z.; Gao, D.; Li, J. Effects of adenovirus vectors mediated human lactoferrin cDNA on mice bearing EMT6 breast carcinoma. Die Pharm. 2011, 66, 704-709.

95. Li, W.Y.; Li, Q.W.; Han, Z.S.; Jiang, Z.L.; Yang, H.; Li, J.; Zhang, X.B. Growth suppression effects of recombinant adenovirus expressing human lactoferrin on cervical cancer in vitro and in vivo. Cancer Biother. Radiopharm. 2011, 26, 477-483. [CrossRef] [PubMed]

96. Freiburgahus, C.; Janicke, B.; Lindmark-Mansson, H.; Oredsson, S.M.; Paulsson, M.A. Lactoferricin treatment decreases the rate of cell proliferation of a human colon cancer cell line. J. Dairy Sci. 2009, 92, 2477-2484. [CrossRef] [PubMed]

97. Lönnerdal, B.; Jiang, R.; Du, X. Bovine lactoferrin can be taken up by the human intestinal lactoferrin receptor and exert bioactivities. J. Pediatr. Gastroenterol. Nutr. 2011, 53, 606-614. [CrossRef] [PubMed] 
98. Kuhara, T.; Iigo, M.; Itoh, T.; Ushida, Y.; Sekine, K.; Terada, N.; Okamura, H.; Tsuda, H. Orally administered lactoferrin exerts an antimetastatic effect and enhances production of IL-18 in the intestinal epithelium. Nutr. Cancer 2000, 38, 192-199. [CrossRef] [PubMed]

99. Iigo, M.; Shimamura, M.; Matsuda, E.; Fujita, K.; Nomoto, H.; Satoh, J.; Kojima, S.; Alexander, D.B.; Moore, M.A.; Tsuda, H. Orally Orally administered bovine lactoferrin induces caspase-1 and interleukin-18 in the mouse intestinal mucosa: A possible explanation for inhibition of carcinogenesis and metastasis. Cytokine 2004, 25, 36-44. [CrossRef] [PubMed]

100. Pan, W.R.; Chen, P.W.; Chen, Y.L.; Hsu, H.C.; Lin, C.C.; Chen, W.J. Bovine lactoferricin B induces apoptosis of human gastric cancer cell line AGS by inhibition of autophagy at a late stage. J. Dairy Sci. 2013, 96, 7511-7520. [CrossRef] [PubMed]

101. Deng, M.; Zhang, W.; Tang, H.; Ye, Q.; Liao, Q.; Zhou, Y.; Wu, M.; Xiong, W.; Zheng, Y.; Guo, X.; et al. Lactotransferrin acts as a tumor suppressor in nasopharyngeal carcinoma by repressing AKT through multiple mechanisms. Oncogene 2013, 32, 4273-4283. [CrossRef] [PubMed]

102. Letchoumy, P.V.; Mohan, K.V.; Stegeman, J.J.; Gelboin, H.V.; Hara, Y.; Nagini, S. In vitro antioxidative potential of lactoferrin and black tea polyphenols and protective effects in vivo on carcinogen activation, DNA damage, proliferation, invasion, and angiogenesis during experimental oral carcinogenesis. Oncol. Res. 2008, 17, 193-203. [CrossRef] [PubMed]

103. Wolf, J. S.; Li, G.; Varadhachary, A.; Petark, K.; Schneyer, M.; Li, D.; Ongkasuwan, J.; Zhang, X.; Taylor, R.J.; Strome, S.E.; et al. Oral lactoferrin results in T cell-dependent tumor inhibition of head and neck squamous cell carcinoma in vivo. Clin. Cancer Res. 2007, 13, 1601-1610. [CrossRef] [PubMed]

104. Xiao, Y.; Monitto, C.L.; Minhas, K.M.; Sidransky, D. Lactoferrin down-regulates G1 cyclin-dependent kinases during growth arrest of head and neck cancer cells. Clin. Cancer Res. 2004, 10, 8683-8686. [CrossRef] [PubMed]

105. Sakai, T.; Banno, Y.; Kato, Y.; Nozawa, Y.; Kawaguchi, M. Pepsin-digested lactoferrin induces apoptotic cell death with JNK/SAPK activation in oral cancer cells. J. Pharm. Sci. 2005, 98, 41-48. [CrossRef]

106. Richardosn, A.; de Antueno, R.; Duncan, R.; Hoskin, D.W. Intracellular delivery of bovine lactoferricin's antimicrobial core (RRWQWR) kills T-leukemia cells. Biochem. Biophys. Res. Commun. 2009, 388, 736-741. [CrossRef] [PubMed]

107. Mader, J.S.; Salsman, J.; Conrad, D.M.; Hoskin, D.W. Bovine lactoferricin selectively induces apoptosis in human leukemia and carcinoma cell lines. Mol. Cancer Ther. 2005, 4, 612-624. [CrossRef] [PubMed]

108. Lu, Y.; Zhang, T.F.; Shi, Y.; Zhou, H.W.; Chen, Q.; Wei, B.Y.; Wang, X.; Yang, T.X.; Chinn, Y.E.; Kang, J.; et al. PFR peptide, one of the antimicrobial peptides identified from the derivatives of lactoferrin, induces necrosis inleukemia cells. Sci. Rep. 2016, 6, 20823. [CrossRef] [PubMed]

109. Lee, S.H.; Hwang, H.M.; Pyo, C.W.; Hahm, D.H.; Choi, S.Y. E2F1-directed activation of Bcl-2 is correlated with lactoferrin-induced apoptosis in Jurkat leukemia T lymphocytes. Biometals 2010, 23, 507-514. [CrossRef] [PubMed]

110. Matsuda, Y.; Saoo, K.; Hosokawa, K.; Yamakawa, K.; Yokohira, M.; Zeng, Y.; Takeuchi, H.; Imaida, K. Post-initiation chemopreventive effects of dietary bovine lactoferrin on 4-(methynitrosamino)-1-(3-pyridyl)-1butanone-induced lung tumorigenesis in female A/J mice. Cancer Lett. 2007, 246, 41-46. [CrossRef] [PubMed]

111. Son, H.J.; Lee, S.H.; Choi, S.Y. Human lactoferrin controls the level of retinoblastoma protein and its activity. Biochem. Cell Biol. 2006, 84, 345-350. [CrossRef] [PubMed]

112. Wang, S.; Tu, J.; Zhou, C.; Li, J.; Huang, L.; Tao, L.; Zhao, L. The effect of Lfcin-B on non-small cell lung cancer $\mathrm{H} 460$ cells is mediated by inhibiting VEGF expression and inducing apoptosis. Arch. Pharm. Res. 2015, 38, 261-271. [CrossRef] [PubMed]

113. Eliassen, L.T.; Berge, G.; Leknessund, A.; Wikman, M.; Lindin, I.; Løkke, C.; Ponthan, F.; Johnsen, J.I.; Sveinbjørnsson, B.; Kogner, P.; et al. The antimicrobial peptide, lactoferricin B, is cytotoxic to neuroblastoma cells in vitro and inhibits xenograft growth in vivo. Int. J. Cancer 2006, 119, 493-500. [CrossRef] [PubMed]

114. Arcella, A.; Oliva, M.A.; Staffieri, S.; Aalberti, S.; Grillea, G.; Madonna, M.; Bartolo, M.; Pavone, L.; Giangaspero, F.; Cantore, G.; et al. In vitro and in vivo effect of human lactoferrin on glioblastoma growth. J. Neurosurg. 2015, 123, 1026-1035. [CrossRef] [PubMed]

115. Hoedt, E.; Hardivillé, S.; Mariller, C.; Elass, E.; Perraudin, J.P.; Pierce, A. Discrimination and evaluation of lactoferrin and delta-lactoferrin gene expression levels in cancer cells and under inflammatory stimuli using TaqMan real-time PCR. Biometals 2010, 23, 441-452. [CrossRef] [PubMed] 
116. Benaïssa, M.; Peyrat, J.P.; Hornez, L.; Mariller, C.; Mazurier, J.; Pierce, A. Expression and prognostic value of lactoferrin mRNA isoforms in human breast cancer. Int. J. Cancer 2005, 114, 299-306. [CrossRef] [PubMed]

117. Kanwar, J.R.; Palmano, K.P.; Sun, X.; Kanwar, R.K.; Gupta, R.; Haggarty, N.; Rowan, A.; Ram, S.; Krissansen, G.W. 'Iron-saturated' lactoferrin is a potent natural adjuvant for augmenting cancer chemotherapy. Immunol. Cell Boil. 2008, 86, 277-288. [CrossRef] [PubMed]

118. Kanwar, J.R.; Mahidhara, G.; Kanwar, R.K. Novel alginate-enclosed chitosan-calcium phosphate-loaded iron-saturated bovine lactoferrin nanocar-riers for oral delivery in colon cancer therapy. Nanomedicine 2012, 7, 1521-1550. [CrossRef] [PubMed]

119. Tsuda, H.; Kozu, T.; Iinuma, G.; Ohashi, Y.; Saito, Y.; Saito, D.; Akasu, T.; Alexander, D.B.; Futakuchi, M.; Fukamachi, K.; et al. Cancer prevention by bovine lactoferrin: From animal studies to human trial. Biometals 2010, 23, 399-409. [CrossRef] [PubMed]

120. Furlong, S.J.; Mader, J.S.; Hoskin, D.W. Lactoferricin-induced apoptosis in estrogen- nonresponsive MDA-MB-435 breast cancer cells is enhanced by C6 ceramide or tamoxifen. Oncol. Rep. 2006, 15, 1385-1390. [CrossRef] [PubMed]

121. Massodi, I.; Thomas, E.; Raucher, D. Application of thermally responsive elastin-like polypeptide fused to a lactoferrin-derived peptide for treatment of pancreatic cancer. Molecules 2009, 14, 1999-2015. [CrossRef] [PubMed]

122. Roseanu, A.; Florian, P.E.; Moisei, M.; Sima, L.E.; Evans, R.W.; Trif, M. Liposomalization of lactoferrin enhanced its anti-tumoral effects on melanoma cells. Biometals 2010, 23, 485-492. [CrossRef] [PubMed]

123. Artym, J.; Zimecki, M.; Kruzel, M.L. Effect of lactoferrin on the methotrexate- induced suppression of the cellular and humoral immune response in mice. Anticancer Res. 2004, 24, 3831-3836. [PubMed]

124. Artym, J.; Zimecki, M.; Kuryszko, J.; Kruzel, M.L. Lactoferrin accelerates reconstitution of the humoral and cellular immune response during chemotherapy-induced immunosuppression and bone marrow transplant in mice. Stem. Cells Dev. 2005, 14, 548-555. [CrossRef] [PubMed]

125. Sun, X.; Jiang, R.; Przepiorski, A.; Reddy, S.; Palmano, K.P.; Krissansen, G.W. "Iron-saturated" bovine lactoferrin improves the chemotherapeutic effects of tamoxifen in the treatment of basal-like breast cancer in mice. BMC Cancer 2012, 12, 591. [CrossRef] [PubMed]

126. Guo, H.Y.; Jiang, L.; Ibrahim, S.A.; Zhang, L.; Zhang, H.; Zhang, M.; Ren, F.Z. Orally administered lactoferrin preserves bone mass and microarchitecture in ovariectomized rats. J. Nutr. 2009, 139, 958-964. [CrossRef] [PubMed]

127. Bharadwaj, S.; Naidu, A.G.; Betageri, G.V.; Prasadarao, N.V.; Naidu, A.S. Milk ribonuclease-enriched lactoferrin induces positive effects on bone turnover markers in postmenopausal women. Osteoporos. Int. 2009, 20, 1603-1611. [CrossRef] [PubMed]

128. Cornish, J.; Naot, D. Lactoferrin as an effector molecule in the skeleton. Biometals 2010, 23, 425-430. [CrossRef] [PubMed]

129. Georgieff, M.K. The role of iron in neurodevelopment: Fetal iron deficiency and the developing hippocampus. Biochem. Soc. Trans. 2008, 36, 267-271. [CrossRef] [PubMed]

130. Somm, E.; Larvaron, P.; van de Looij, Y.; Toulotte, A.; Chatagner, A.; Faure, M.; Métairon, S.; Mansourian, R.; Raymond, F.; Gruetter, R.; et al. Protective effects of maternal nutritional supplementation with lactoferrin on growth and brain metabolism. Pediatr. Res. 2014, 75, 51-61. [CrossRef] [PubMed]

131. Szwajkowska, M.; Wolanciuk, A.; Barłowska, J.; Król, J.; Litwińczuk, Z. Bovine milk proteins as the source of bioactive peptides influencing the consumers' immune system. Anim. Sci. Pap. Rep. 2011, 29, 269-280.

132. Brouwer, C.P.; Welling, M.M. Various routes of administration of ( $99 \mathrm{~m})$ Tc-labeled synthetic lactoferrin antimicrobial peptide hLF 1-11 enables monitoring and effective killing of multidrug-resistant Staphylococcus aureus infections in mice. Peptides 2008, 29, 1109-1117. [CrossRef] [PubMed]

133. Gifford, J.L.; Hunter, H.N.; Vogel, H.J. Lactoferricin: A lactoferrin-derived peptide with antimicrobial, antiviral, antitumor and immunological properties. Cell Mol. Life Sci. 2005, 62, 2588-2598. [CrossRef] [PubMed]

134. Flores-Villaseñor, H.; Canizalez-Román, A.; Reyes-Lopez, M.; Nazmi, K.; de la Garza, M.; Zazueta-Beltrán, J.; León-Sicairos, N.; Bolscher, J.G. Bactericidal effect of bovine lactoferrin, LFcin, LFampin and LFchimera on antibiotic-resistant Staphylococcus aureus and Escherichia coli. Biometals 2010, 23, 569-578. [CrossRef] [PubMed] 
135. Wakabayashi, H.; Bellamy, W.; Takase, M.; Tomita, M. Inactivation of Listeria monocytogenes by lactoferricin, a potent antimicrobial peptide derived from cow's milk. J. Food Prot. 1992, 55, 238-240.

136. Dijkshoorn, L.; Brouwer, C.P.; Bogaards, S.J.; Nemec, A.; van den Broek, P.J.; Nibbering, P.H. The synthetic $\mathrm{N}$-terminal peptide of human lactoferrin, $\mathrm{hLF}(1-11)$, is highly effective against experimental infection caused by multidrug-resistant Acinetobacter baumannii. Antimicrob. Agents Chemother. 2004, 48, 4919-4921. [CrossRef] [PubMed]

137. Federico, B.; Pinto, L.; Quintieri, L.; Carito, A.; Calabrese, N.; Caputo, L. Efficacy of lactoferricin B in controlling ready-to-eat vegetable spoilage caused by Pseudomonas spp. Int. J. Food Microbiol. 2015, 215, 179-186. [CrossRef] [PubMed]

138. Sánchez-Gómez, S.; Ferrer-Espada, R.; Stewart, P.S.; Pitts, B.; Lohner, K.; Martínez de Tejada, G. Antimicrobial activity of synthetic cationic peptides and lipopeptides derived from human lactoferricin against Pseudomonas aeruginosa planktonic cultures and biofilms. BMC Microbiol. 2015, 15, 137. [CrossRef] [PubMed]

139. León-Calvijo, M.A.; Leal-Castro, A.L.; Almanzar-Reina, G.A.; Rosas-Pérez, J.E.; García-Castañeda, J.E.; Rivera-Monroy, Z.J. Antibacterial activity of synthetic peptides derived from lactoferricin against Escherichia coli ATCC 25922 and Enterococcus faecalis ATCC 29212. Biomed. Res. Int. 2015, 2015, 453826. [CrossRef] [PubMed]

140. Tang, Z.; Zhang, Y.; Stewart, A.F.; Geng, M.; Tang, X.; Tu, Q.; Yin, Y. High-level expression, purification and antibacterial activity of bovine lactoferricin and lactoferrampin in Photorhabdus luminescens. Protein Expr. Purif. 2010, 73, 132-139. [CrossRef] [PubMed]

141. Cruz, J.; Ortiz, C.; Guzmán, F.; Cárdenas, C.; Fernandez-Lafuente, R.; Torres, R. Design and activity of novel lactoferrampin analogues against O157:H7 enterohemorrhagic Escherichia coli. Biopolymers 2014, 101, 319-328. [CrossRef] [PubMed]

142. van der Kraan, M.I.; Nazmi, K.; van 't Hof, W.; Amerongen, A.V.; Veerman, E.C.; Bolscher, J.G. Distinct bactericidal activities of bovine lactoferrin peptides LFampin 268-284 and LFampin 265-284: Asp-Leu-Ile makes a difference. Biochem. Cell. Biol. 2006, 84, 358-362. [CrossRef] [PubMed]

143. Wang, W.Y.; Wong, J.H.; Ip, D.T.; Wan, D.C.; Cheung, R.C.; Ng, T.B. Bovine Lactoferrampin, Human Lactoferricin, and Lactoferrin 1-11 Inhibit Nuclear Translocation of HIV Integrase. Appl. Biochem. Biotechnol. 2016, 179, 1202-1212. [CrossRef] [PubMed]

144. Ng, T.B.; Cheung, R.C.; Wong, J.H.; Wang, Y.; Ip, D.T.; Wan, D.C.; Xia, J. Antiviral activities of whey proteins. Appl. Microbiol. Biotechnol. 2015, 99, 6997-7008. [CrossRef] [PubMed]

145. Tsou, Y.A.; Huang, H.J.; Lin, W.W.; Chen, C.Y. Investigation of anti-infection mechanism of lactoferricin and splunc-1. Evid. Based Complement. Alternat. Med. 2014, 2014, 907028. [CrossRef] [PubMed]

146. Jenssen, H.; Sandvik, K.; Andersen, J.H.; Hancock, R.E.; Gutteberg, T.J. Inhibition of HSV cell-to-cell spread by lactoferrin and lactoferricin. Antivir. Res. 2008, 79, 192-198. [CrossRef] [PubMed]

147. Mistry, N.; Drobni, P.; Näslund, J.; Sunkari, V.G.; Jenssen, H.; Evander, M. The anti-papillomavirus activity of human and bovine lactoferricin. Antivir. Res. 2007, 75, 258-265. [CrossRef] [PubMed]

148. Lupetti, A.; Brouwer, C.P.; Bogaards, S.J.; Welling, M.M.; de Heer, E.; Campa, M.; van Dissel, J.T.; Friesen, R.H.; Nibbering, P.H. Human lactoferrin-derived peptide's antifungal activities against disseminated Candida albicans infection. J. Infect. Dis. 2007, 196, 1416-1424. [CrossRef] [PubMed]

149. Sengupta, J.; Saha, S.; Khetan, A.; Sarkar, S.K.; Mandal, S.M. Effects of lactoferricin Bagainst keratitis-associated fungal biofilms. J. Infect. Chemother. 2012, 18, 698-703. [CrossRef] [PubMed]

150. Vylkova, S.; Sun, J.N.; Edgerton, M. The role of released ATP in killing Candida albicans and other extracellular microbial pathogens by cationic peptides. Purinergic Signal. 2007, 3, 91-97. [CrossRef] [PubMed]

151. Tang, X.S.; Shao, H.; Li, T.J.; Tang, Z.R.; Huang, R.L.; Wang, S.P.; Kong, X.F.; Wu, X.; Yin, Y.L. Dietary supplementation with bovine lactoferrampin-lactoferricin produced by Pichia pastoris fed-batch fermentation affects intestinal microflora in weaned piglets. Appl. Biochem. Biotechnol. 2012, 168, 887-898. [CrossRef] [PubMed]

152. Haney, E.F.; Nazmi, K.; Lau, F.; Bolscher, J.G.; Vogel, H.J. Novel lactoferrampin antimicrobial peptides derived from human lactoferrin. Biochimie 2009, 91, 141-154. [CrossRef] [PubMed]

153. Leitch, G.J.; Ceballos, C. A role for antimicrobial peptides in intestinal microsporidiosis. Parasitology 2009, 136, 175-181. [CrossRef] [PubMed] 
154. López-Soto, F.; León-Sicairos, N.; Nazmi, K.; Bolscher, J.G.; de la Garza, M. Microbicidal effect of the lactoferrin peptides lactoferricin17-30, lactoferrampin265-284, and lactoferrin chimera on the parasite Entamoeba histolytica. Biometals 2010, 23, 563-568. [CrossRef] [PubMed]

155. Eliassen, L.T.; Berge, G.; Sveinbjørnsson, B.; Svendsen, J.S.; Vorland, L.H.; Rekdal, Ø. Evidence for a direct antitumor mechanism of action of bovine lactoferricin. Anticancer Res. 2002, 22, 2703-2710. [PubMed]

156. Chen, H.Y.; Mollstedt, O.; Tsai, M.H.; Kreider, R.B. Potential clinical applications of multi-functional milk proteins and peptides in cancer management. Curr. Med. Chem. 2014, 21, 2424-2437. [CrossRef] [PubMed]

157. Yin, C.M.; Wong, J.H.; Xia, J.; Ng, T.B. Studies on anticancer activities of lactoferrin and lactoferricin. Curr. Protein Pept. Sci. 2013, 14, 492-503. [CrossRef] [PubMed]

158. Zheng, Y.; Chen, P.; Guo, X.; Ma, J.; Li, G. New function of lactoferrin: Protection against cancer development and metastasis. Zhong Nan Da Xue Xue Bao Yi Xue Ban 2012, 37, 1284-1289. [PubMed]

(C) 2016 by the authors; licensee MDPI, Basel, Switzerland. This article is an open access article distributed under the terms and conditions of the Creative Commons Attribution (CC-BY) license (http://creativecommons.org/licenses/by/4.0/). 